\title{
АСНОЎНЫЯ ВЫНІКІ АРХЕАЛАГІЧНЫХ ДАСЛЕДАВАННЯЎ НА ПАЎДНЁВЫМ ЗАХАДЗЕ БЕЛАРУСІ Ў РАМКАХ РЭСТАЎРАЦЫЙНЫХ ПРАЦ НА МЯЖЫ ХХ-ХХI СТАГОДДЗЯЎ
}

Ключавыя словы: Археалогія; рэстаўрацыя; рэзідэнцыя; палац; замак KEYwORDS: Archeology; restoration; residence; palace; castle

Архітэктурныя аб'екты, на якіх праводзяцца апошнім часам рэстаўрацыйныя працы, часта з'яўляюцца значнымі помнікамі гісторыі i ўнесены ў Дзяржаўны спіс па ахове гісторыка-культурнай спадчыны. Пачынаючы падрыхтоўку праектнай дакументацыі для рэстаўрацыі такіх помнікаў, архітэктары сутыкаюцца 3 неабходнасцю правядзення першапачатковых комплексных навуковых даследаванняў па дадзенаму аб'екту. Археалагічнае вывучэнне з'яўляецца неад'емнай часткай гэтых даследаванняў. Менавіта яно дае архітэктарам адказы на пытанні, звязаныя 3 асаблівасцямі канструктыўных элементаў архітэктурнага помніка, якія былі страчаны ў выніку разбурэнняў. У сувязі з гэтым, роля археалагічных даследаванняў на рэстаўруемых помніках няспынна павялічваецца.

Паўднёва-заходняя Беларусь мяжуе з Польшчай і Ўкраінай, што безумоўна паўплывала на з'яўленне на даддзенай тэррыторыі знакавых гісторыка-архітэктурных помнікаў і іх развіццё ў кантэксце агульных гістарчных і культурных працэсаў, характэрных для Цэнтральнай і Ўсходняй Еўропы. Брэсцкая вобласць, якая размяшчаецца на паўднёвым захадзе Беларусі багатая на помнікі археалогіi і архітэктуры, даследаванне і рэстаўрацыя якіх сёння з'яўляюцца неад'емнай часткай гісторыка-археалагічнага вывучэння нашай Бацькаўшчыны навуковымі, адукацыйнымі і рэстаўрацыйнапраектнымі ўстановамі. Спецыялісты-археолагі Інстытута гісторыі 
Нацыянальнай Акадэміі навук Беларусі праводзяць на Берасцейскай зямлі штогадовыя даследаванні помнікаў эпохі камня і бронзы (Лакіза В. Л., Калечыц А. Г.), помнікаў жалезнага веку (Белявец В. Р.) і эпохі сярэднявечча (Лысенка П. Ф., Іоў А. В.). Значны аб'ём працы па правядзенню археалагічных даследаванняў архітэктурных помнікаў Берасцейшчыны за апошнія гады зроблены намаганнямі УА „Брэсцкі дзяржаўны ўніверсітэт імя А. С. Пушкіна” і ААТ „Брэстрэстаўрацыяпраект”. Археалагічныя экспедыцыі, арганізаваныя гэтымі ўстановамі, ўзначальвае кандыдат гістарычных навук, дацэнт А. А. Башкоў.

Усе мерапрыемствы па ахове гісторыка-культурнай спадчыны Беларусі i, неад'емная іх частка, даследаванні археалагічных помнікаў, грунтуюцца на шэрагу нарматыўна-прававых актаў. Крымінальны кодэкс Рэспублікі Беларусь прыняты Палатай прадстаўнікоў 2 чэрвеня 1999 г. і ўхвалены Саветам Рэспублікі 24 чэрвеня 1999 г. утрымлівае шэраг артыкулаў (344-347) дзе акрэслена адказнасць за знічтажэнне, пашкоджанне і знявагу гісторыка-культурных помнікаў.

Акрамя таго, яшчэ шэраг законаў і пастаноў рэгулююць дзейнасць, звязаную з аховай і рэстаўрацыяй гісторыка-культурных і архітэктурных помнікаў: Закон Рэспублікі Беларусь 5 чэрвеня 2004 г. № 300-3 „Аб архітэктурнай, горадабудаўнічай і будаўнічай дзейнасці ў Рэспубліцы Беларусь” (прыняты Палатай прадстаўнікоў 8 чэрвеня 2004 года, ухвалены Саветам Рэспублікі 16 чэрвеня 2004 года); Закон Рэспублікі Беларусь 9 студзеня 2006 г. № 98-3 „Аб ахове гісторыка-культурнай спадчыны Рэспублікі Беларусь (прыняты Палатай прадстаўнікоў 12 снежня 2005 года, ухвалены Саветам Рэспублікі 21 снежня 2005 года); пастанова Савета міністраў Рэспублікі Беларусь 22 мая 2002 г. № 651 „Аб зацвярджэнні палажэння аб ахове археалагічных аб'ектаў пры правядзенні земляных і будаўнічых работ" (пастанова Савета міністраў Рэспублікі Беларусь 15 чэрвеня 2006 г. № 762 з дапаўненнямі).

Асобна можна выдзяліць пастанову Савета міністраў Рэспублікі Беларусь 8 кастрычніка 2002 г. № 1395 „Аб сістэме мер, якія забяспечваюць правядзенне рэстаўрацыйна-узнаўляльных прац на найбольш важных аб'ектах гісторыка-культурнай спадчыны Рэспублікі Беларусь”. Дадзеная пастанова ўказвае на першачарговасць аб'ектаў у кожнай вобласці, якія патрабуюць тэрміновай рэстаўрацыі і рэканструкцыі. Па Брэсцкай вобласці гэта шэраг вядомых помнікаў: Камянецкая вежа XIII ст., палац XIX ст. у в. Паланечка Баранавіцкага р-на, палаца-паркавы комплекс XVII-XIX стст. у г. Высокае, сядзіба XIX ст. ў в. Грамяча Камянецкага 
p-на, палаца-паркавы комплекс XVIII ст., у в. Скокі Брэсцкага р-на, калегія езуітау XVII ст. у г. Пінск, палацавы комплекс XVI-XVIII стст., у г.п. Ружаны, палаца-паркавы комплекс XIX ст., у г. Косава Івацэвіцкага р-на.

У рамках дадзенай праграмы на рэстаўруемых помніках у Камянцы, Косаве, Ружанах, Скоках былі праведзены археалагічныя даследаванні. Акрамя гэтага даследаванні праводзіліся яшчэ на шэрагу помнікаў: радавая капліца Ажэшкаў у в. Заказель Драгічынскага р-на, кляштар картэзіянцаў ў горадзе Бяроза і інш.

Даследаванні Камянца (Камянецкі р-н) праводзіліся ў 1998-2004 гг. i ўключалі ў сябе вывучэнне культурных напластаванняў замчышча і старажытнага горада, а таксама гарадскога могільніка XIV ст. (Фот. 1).

У ходзе археалагічнага вывучэння старажытнага Камянца, удалося знайсці і вывучыць культурныя пласты канца XIII-XVIII стст. Быў лакалізаваны старажытны замак авальнай формы прыкладна 40 х 40 м, які знаходзіўся на захад ад вежы (сённяшняя тэрыторыя гімназіi). У выніку была зроблена спроба рэканструкцы сістэмы абарончых збудаванняў, якая ўяўляла сабой дзве адасобленыя выспы, абнесеныя ірвом і валам. На заходняй выспе размяшчаўся першапачатковы замак, на ўсходняй - вежа.

Падчас вывучэння культурных напластаванняу зроблены цікавыя знаходкі: прылады працы, зброя, значная калекцыя манет XVI-XX стст., рэчы паўсядзённага побыту i ўпрыгожванні. Унікальнай знаходкай 3'яўляецца кафля XVI ст. 3 партрэтнай выявай маладога чалавека ў сярэднявечнай вопратцы. Матэрыялы перадмацерыковага пласта далі сведчанні пра існаванне на месцы старажатнага замка паселішча X ст. (Археалогія...).

У выніку вывучэння грунтовага гарадскога могільніка зафіксавана: 5 цэлых пахаванняў; 11 пашкоджаных пахаванняў, якія захаваліся ў выглядзе згрупавання костак і чэрапоў. Пахаванні знаходзіліся на рознай глыбіні, ад 20 см да 75 см. Толькі два дзіцячых пахаванні заглыбляліся ў мацерык на 16 см і 24 см адпаведна. Арыентацыя касцякоў пераважна заходняя, у некаторых выпадках 3 невялікім адхіленнем на паўднёвы-захад. Толькі адно пахаванне зарыентавана на паўночны-захад.

У двух пахаваннях знойдзены суправаджальны інвентар - адзінаццаць фрагментаў бронзавых дэкаратыўных дэталяў на пас, якія знаходзіліся ў раёне жывата на касцяку кабеты, і два касцяных гузікі ў раёне грудзей на касцяку падлетка (верагодна дзяўчынкі).

Практычная адсутнасць пахавальнага інвентару, арыентацыя, палажэнне і ўзроўні залягання касцякоў, сведчаць пра неадначасовасць 
пахаванняў і іх хрысціанскі абрад. Таксама, можна сцвярджаць аб пэўнай сістэмнасці ў пахаваннях. Можна рэканструяваць 4 шэрагі пахаванняў. Акрамя таго, удалося прасачыць два пахаванні ў трунах. Гэта пахаванні двух дарослых людзей, мужчыны i жанчыны 3 лёгкім адхіленнем ў арыентацыі на пауднёвы-захад. Менавіта ў галавах гэтых пахаванняў на глыбіні ад 15 см прасочаны развалы двух ганчарных гаршкоў, пастаўленых уверх донцам, што паказвае на сляды пахавальнай, альбо памінальнай трызны.

Чарговасць дзіцячых i падлеткавых пахаванняў разам 3 дарослымі ў кожным 3 шэрагаў могільніка штурхае на думку аб пэўнай сваяцкай прыналежнасці, альбо нават сямейнасці, пахаваных. Аднак правядзенне антрапалагічнага аналізу костных рэшткаў дасць нам значна большую інфармацыю, што, безумоўна, з'яўляецца прыярытэтным накірункам у далейшым вывучэнні могільніка каля г. Камянец (Башкоў, Іоў 2006; Башкоў 2011a)

Уся археалагічная калекцыя старажытнага Камянца i гарадскога могільніка сталі асновай для стварэння экспазіцыі філіяла Брэсцкага абласнога краязнаўчага музея, які месціцца ў адрэстаўраванай Камянецкай вежы.

З 2008 г. пачалася рэстаўрацыя палаца Пуслоўскіх XIX ст. у горадзе Косава Івацэвіцкага р-на (Фот. 2). Мэтамі археалагічных даследаванняў 2008-2013 гг. сталі - пошук і збор археалагічнага матэрыялу ў ходзе вынасу i пераборкі грунту з памяшканняў палаца, а так сама вывучэнне малых архітэктурных аб’ектаў на тэрыторыі палаца-паркавага комплексу.

Праведзеныя археалагічныя працы сталі лагічным працягам даследаванняў, распачатых у 1990 г. і важным складнікам комплексных прац па рэстаўрацыі палаца XIX ст. У ходзе археалагічных даследаванняў дадзенага помніка, быў сабраны значны археалагічны матэрыял, які адлюстроўвае паўсядзённае жыццё палаца ў розныя перыяды яго функцыянавання. Злакалізаваны i вывучаны стан захавання рэшткаў заходняй, ўсходняй і паўднёвай уяздных брам (Башков 2011b).

Усе здабытыя ў ходзе вывучэння археалагічныя матэрыялы актыўна выкарыстоўваюцца ў працах па ўзнаўленню ўнутраннага інтэр'еру і знешняга аблічча Косаўскага палаца.

У 2008 г. пачаліся рэстаўрацыя i рэканструкцыя ўяздной брамы і прылеглых да яе флігеляў Ружанскага палаца Сапегаў XVIII ст. (Фот. 3). У ходзе праведзеных археалагічных прац у г.п. Ружаны (Пружанскі р-н) y̆ 2008 г. на тэррыторыі палацавага комплексу XVI-XVIII стст. былі 
даследаваны культурныя пласты на ўнутраннай прасторы ўсходняга флігеля, які прылягае да ўяздной брамы.

Было вызначана, што на працягу існавання флігеля, ён неаднаразова разбураўся і аднаўляўся. У $30-x$ гг. ХХ ст. у флігіле знаходзіліся вытворчыя майстэрні, што прывяло да значных пашкоджанняў культурных напластаваняў. Верхнія пласты па ўсёй плошчы на глыбіню да 70 см былі перамешаны i насычаны бітай цэглай і вялікімі камянямі. Артэфакты, знойдзеныя ў ix, пераважна датуюцца XIX - п.п. XX стст. Толькі ніжэйшы пласт, таўшчынёй да 20 см, утрымоўваў матэрыялы канца XVIII ст. У цэнтральнай частцы будынку было адкрыта заваленае падвальнае памяшканне, якое існавала ў п.п. ХХ в. У паўночна-усходняй частцы флігеля прасочана драўляна-цагляная канструкцыя тагож перыяду.

Працы 2010 і 2011 гадоў ва ўнутраннай прасторы тэатральнага (усходнягя) корпуса паказалі на цудоўную захаванасць каменна-цагляных падмуркаў унутраннай каланады, якая была канструктыўнай асновай для падтрымкі стрэхавых перакрыццяў будынку і абсталявання тэатральных лодж. Ускрытыя канструкцыі каланады далі архітэктарам аб'ектыўныя памеры канструкцыі i адпраўныя кропкі для падрыхтоўкі праектнай дакументацыі.

У 2011 г. былі даследаваны культурныя пласты ва ўнутраннай прасторы заходняга флігеля Ружанскага палаца. У выніку было вызначана, што на працягу існавання ён неаднаразова разбураўся і рэканструяваўся. У першай палове ХХ ст. ва флігелі знаходзіліся майстэрні па вырабу пячной кафлі, што прывяло да значнага знішчэння культурных напластаванняў. На значнай плошчы захаваліся рэшткі каменна-бетонных канструкцый першай паловы XX ст. Толькі ніжэйшыя пласты, якія захаваліся паміж імі ўтрымоўвалі матэрыялы канца XVI-XVIII стст. Вывучэнне дадзеных пластоў дазволіла сцвердзіць існаванне на месцы ўзведзенага заходняга флігеля другой паловы XVIII ст. будынка ранейшай рэзідэнцыі Сапегаў датуемага XVII ст. Былі зафіксаваныя рэшткі каменна-цаглянай канструкцыі, знішчанай пажарам, верагодна падчас магнацкай міжусобнай барацьбы канца XVII ст. і сабрана цудоўная каллекцыя артэфактаў дадзенага перыяду. Унікальнасць гэтай калекцыі ў тым, што вялікі керамічны матэрыял добра датуемы, дзякуючы адпаведнаму кантэксту з нумізматычным матэрыялам.

Сабраны археалагічны матэрыял стаў асновай для экспазіцыі музея, адкрытага ў адрэстаўраваных флігелях Ружанскага палаца i дазволіў 
прасачыць асноўныя этапы функцыянавання гэтага помніка на працягу чатырох стагоддзяў (Башкоў 2010).

Падчас прац у падвальных памяшканнях капліцы-усыпальніцы ў вёсцы Заказель Драгічынскага р-на, сярод смецця былі знойдзеныя артэфакты, якія датуюцца XIX - п.п. XX стст.: чугунныя літыя фрагменты ўнутранняга інтэр'еру капліцы, фрагменты драўлянай разьбы, бронзавыя дэталі трун, фрагменты слуцкіх паясоў, суконнай абіўкі трун і вопраткі пахаваных і г.д. (Фот. 4).

Таксама знойдзена значная колькасць чалавечых костак з разбураных пахаванняў XIX ст. Вынікі антрапалагічнага аналізу падцвердзілі факт знаходжання ў капліцы парэшткаў чатырох прадстаўнікоў роду Ажэшкаў (Башков, Емельянчик 2010).

У канцы чэрвеня 2008 г. Драгічынскім раённым аддзелам культуры было арганізавана перазахаванне парэшткаў прадстаўнікоў роду Ажэшкаў. Яны былі пахаваны каля капліцы ў адной магіле.

У выніку праведзеных прац 2009 г. у горадзе Бяроза на тэрыторыі картэзіянскага кляштара XVII ст. былі даследаваны культурныя пласты на прасторы, прылеглай да ўяздной брамы і ў яе сярэдзіне (Фот. 5).

Было вызначана, што на працягу існавання брамы, насціл ва ўяздной прасторы некалькі разоў мяняўся. Пад каменнай маставой залягаў культурны пласт насычаны артэфактамі. Былі зачышчаны падмуркі, якія знаходзяцца пад існуючай брамай і выходзяць за яе межы. Гэта дае падставы меркаваць, што існавала больш ранняя пабудова, падмурак якой быў адаптаваны пад будаўніцтва ўяздной брамы кляштара. Таксама былі зафіксаваны камні для падтрымкі падлогавых лаг. Менавіта паміж імі ў мацерыковай яме быў знойдзены келіх “веніцыянскага тыпу”, які датуецца XVI-XVII стст. Артэфакты, знойдзеныя ў культурным пласце, датуюцца першай паловай XVII ст - часам, які папярэднічаў пабудове ўяздной брамы. Такім чынам, архітэктурна-археалагічныя даследаванні дазволілі прасачыць асноўныя этапы трансфармацыі і функцыянавання гэтага збудавання на працягу трох стагоддзяў (Башкоў 2010).

У ходзе рэстаўрацыйных прац палаца Нямцэвічаў XVIII ст. у вёсцы Скокі Брэсцкага р-на былі праведзены археалагічныя даследаванні прылеглай да палаца тэррыторыі ў 2013 годзе (Фот. 6). У выніку былі знойдзены і вывучаны рэшткі аднаго з флігеляў (заходнягя), які з'яўляўся састаўной часткай усяго палаца-паркавага комплексу. Зафіксавана здавальняючая захаванасць падмуркаў i ўнутранных канструкцый будынка, сярод якіх: печкі, унутранныя перагародкі, падлогавы насціл, 
базы пад унутранныя калонны. Былі ўстаноўлены аб'ектыўныя памеры ўсяго флігеля - 8,4 х 32,4 м.

Ускрытыя канструкцы флігеля паказалі на неаднарозувую рэканструкцыю ўнутранных памяшканняў, зыходзячы са зменаў ix функцыянальнага прызначэння. Былі зафіксаваныя сляды чатырох падлогавых насцілаў: першапачатковы драўляны другой паловы XVIII ст., каменны (пакладзены ў першай палове XX ст.), цагляны (пакладзены на мяжы 40-50-х гг. XX ст.), бятонны (пакладзены 50 - 60 - я гг. XX ст.).

У ходзе даследаванняў культурных пластоў усярэдзіне i звонку флігеля, была сабрана значная каллекцыя археалагічнага матэрыялу датуемага XVII - першай паловай XX стст. Сярод яго выдзяляецца нумізматычная каллекцыя срэбных, білонавых і медных манет 3 розных рэгіёнаў Еўропы, разнастайны керамічны матэрыял з шыкоўна аздобленымі кафлямі, а таксама шматлікія шкляныя вырабы. Увесь сабраны матэрыял зойме належнае месца ў экспазіцы Гісторыка-мемарыяльнага музея “Сядзіба Нямцэвічаў”, якая нядаўна адкрылася ў залах адрэстаўраванага палаца.

Аднак заходні флігель адкрыты і даследаваны толькі на 60 атсоткаў. 3-за адсутнасці фінансавання, працы па вывучэнню дадзенага збудавання прыпынены. Ускрытыя канструкцыі чакаюць адпаведнага рашэння ці то аб іх кансервацыі, ці то аб узнаўленні цэлага будынку на аснове старых падмуркаў. Але толькі далейшыя археалагічныя даследаванні дадзенага аб’екта дазволяць праектантам пачаць паўнавартасную працу па падрыхтоуцы праектнай дакументацыі 3 мэтай магчымага будучага ўзнаўлення заходняга флігеля, як неад'емнай часткі адзінага архітэктурнага комплекса XVIII ст. - радавой сядзібы Нямцэвічаў (Башков 2014).

Негледзячы на значныя вынікі архітэктурна-археалагічных даследаванняў на гісторыка-архітэктурных помніках паўднёва-заходняй Беларусі ў апошнія гады, існуе шэраг праблем, якія адбіваюцца на стане археалагічнага вывучэння ў рамках рэстаўрацыйных прац не толькі на рэгіянальным, але і дзяржаўным узроўні.

Галоўнай праблемай з'яўляецца недахоп кваліфікаваных кадраў. Нізкі ўзровень папулярызацы археалогіi ў беларускім грамадстве не садзейнічае павышэнню цікаўнасці да гэтай навукі, а як следства колькасць прэтэндэнтаў на атрыманне археалагічнай адукацыі мінімальна. Праўда зараз рэзка ўзрасла актыўнасць, так званых, „чорных капацеляў”, якія прывабленыя лёккай нажывай, узброіўшыся металашукальнікамі, руйнуюць археалагічныя i архітэктурныя помнікі ў пошуках скарбаў і антыкварыяту. 
Акрамя гэтага, у апошнія гады ідзе імклівая забудова і рэстаўрацыя гістарычных гарадскіх цэнтраў па ўсёй тэрыторыі Беларусі. Негледзячы на наяўнасць адпаведных нарматыўна-прававых актаў, будаўнічыя і праектныя арганізацыі парушаюць іх, не звяртаючыся да паслуг археалагічнага нагляду, неабходнага пры падрыхтоўцы праектнай дакументацыі, а таксама правядзенні земляных і будаўнічых прац. Трэба адзначыць, што гэта становіца магчымым пры не своечасовай рэакцыі і не скаардэнаванасці дзействау дзяржаўных, навуковых і грамадскіх устаноў па ахове гісторыкакультурнай спадчыны.

Такім чынам, негледзячы на шэраг праблем і цяжкасцяў у археалагічнай працы на рэстаўруемых архітэктурных помніках, апошнія гады далі значныя вынікі і паказалі вялікія перспектывы комплекснага і сістэмнага вывучэння розначасовых помнікаў архітэктуры паўднёва-заходняй Беларусі, а таксама неабхонасць шчыльнага супрацоўніцтва навуковых, адукацыйных і рэстаўрацыйных устаноў у дадзеным накірунку.

doc. dr Аляксандр Башкоў

Brzeski Uniwersytet Państwowy im. Aleksandra Puszkina

224016 Brześć (Białoruś)

Bulwar Kosmonautów 21

\section{БИБЛИОГРАФИЯ}

Археалогія...(2009), Археалогія Беларусі, [w:] Энцььлапедыл, Мінск, с. 412-413.

Башкоу А. А. (Башков А. А) (2010), Археалагічная навука Берасиейшчыны на сучаснылм этапе развіщчия „Białorutenistyka Białostocka”, T. 2, Białystok, s. 259-265.

Башкоў А. А. (Башков А. А) (2011а), Грунтовы могільнік 14 cm. у ваколіцах Камянца (вынікі даследаванняу 1998-2004 г., [w:] In silvis, campis... et urbe. Średniowieczny obrzqdek pogrzebowy na pograniczu polsko-ruskim, Rzeszów-Sanok, s. 305-310.

Башкоў А. А. (Башков А. А) (2011b), Архитектурно-археологические исследования 2008 г. в Коссовском дворие 19 в.. „Матэрыялы па археалогіі Беларусі”, Вып. 20, Археалагічныя даследаванні на Беларусі ў 2008 г., Беларуская навука, Мінск, с. 387-392.

Башкоў А. А. (Башков А. А) (2014), Dwór Niemcewiczów w Skokach w świetle badań archeologicznych, „Echa Polesia”, nr 3, s. 79-80. 
Башков А., Емельянчик О. (2010), Родовая каплицุа Ожешков, „Матеріали і дослідження з археології Прикарпаття і Волыні”, Вип. 14, Львів, c. $339-344$.

Башкоў А. А., Іоў А. В. (2006), Археалагічныя даследаванні Камянца і ваколіи у 1997-2004г2, [в:] Камянецкія чытанні. Матэрыялы рэспубліканскай навукова-практычнай канферэниылі (Камянец 4 верасня 2005 г.), ВТАА Права і эканоміка, Мінск, с. 14-19.

\section{STRESZCZenie}

\section{GŁÓWNE WYNIKI BADAŃ ARCHEOLOGICZNYCH \\ W POŁUDNIOWO-ZACHODNIEJ BIAŁORUSI W RAMACH PRAC KONSERWATORSKICH NA PRZELOMIE XX I XXI WIEKU}

W południowo-zachodniej Białorusi (obszar województwa brzeskiego) znajduje się kilka wybitnych obiektów architektonicznych, na których ostatnio przeprowadzono prace konserwatorskie oraz restauracyjne. Obiekty te są znaczące ze względu na ich rolę w historii i kulturze Białorusi.

W trakcie przygotowania dokumentacji projektowej na potrzeby renowacji tych zabytków, architekci spotykają się z koniecznością przeprowadzenia pierwszego etapu prac - kompleksowych badań naukowych, których integralną częścią są badania archeologiczne.

W Białorusi są odpowiednie akty prawne, regulujące działalność w zakresie ochrony i renowacji zabytków historycznych, archeologicznych, kulturowych i architektonicznych. W ramach programu rządowego w szeregu miejscowościach: Kamieńcu, Kosowie, Różanach, Skokach, Zakozielu, Berezie Kartuskiej i innych, prowadzono badania archeologiczne.

Badania starożytnego Kamieńca przeprowadzono w latach 1998 -2004. Obejmowały one teren przyległy do istniejącej do dziś baszty murowanej, zbudowanej w latach 70 . XIII wieku. W wyniku badań archeologicznych dokonano rekonstrukcji systemu obronnego miasta, fukcjonującego od końca XIII do XVIII wieku, oraz odnaleziono pierwotny cmentarz mieszkańców grodu.

Od roku 2008 trwają prace restauracyjne w pałacu Pusłowskich, z pierwszej połowy XIX wieku, w miejscowości Kosawa (rejon iwacewicki). W trakcie badań archeologicznych realizowanych w latach 2008-2013 został pozyskany liczny materiał zabytkowy. Odkryto relikty bram wjazdowych: zachodniej, wschodniej i południowej.

W 2008 roku rozpoczento prace restauracyjne pałacu Sapiehów w Różanie (rejon prużański). Pierwsza została odbudowana brama wjazdowa z przyległymi do niej budyn- 
kami-skrzydłami. W trakcie prac archeologicznych na terenie kompleksu pałacowego z XVI-XVIII wieku zostały zbadane warstwy kulturowe na przestrzeni wewnętrznej skrzydeł pałacowych. Wyniki badań dowiodły, że wewnętrzny plan budynków przylegających do bramy wjazdowej wielokrotnie się zmieniał. Oprócz tego, w warstwach kulturowych zachodniego skrzydła, odnaleziono relikty starszego budynku - dowód na istnienie wcześniejszej, funkcjonującej w XVI-XVII w. rezydencji Sapiehów.

Prace archeologiczne w 2010 i 2011 roku w wewnętrznej przestrzeni budynku teatralnego pałacu Sapiehów wykazały bardzo dobry stan zachowania fundamentów wewnętrznej kolumnady, wspierającej konstrukcje dachu i urządzeń teatralnych loży.

Podczas prac w podziemiach kaplicy rodu Orzeszków we wsi Zakoziel (rejon drohiczyński), wśród gruzu i śmieci odnaleziono artefakty datowane na XIX w. - początek XX w.: fragmenty wnętrza kaplicy z metali i drzewna, brązowe elementy trumien, fragmenty pasów ze Słucka. Również odnaleziono znaczną ilość ludzkich kości pochodzących ze zniszczonych grobów z XIX wieku. Wyniki analizy antropologicznej potwierdziły obecność pochówków czterech przedstawicieli rodu Orzeszków.

W wyniku prac archeologicznych 2009 roku w miejscowości Bereza (Bereza Krtuska) (rejon bereski) na terenie klasztoru kartuzów z XVII w., zostały zbadane warstwy kulturowe w wewnętrznej przestrzeni bramy wjazdowej. Wyniki badań pozwalają sugerować istnienie reliktów starszego budynku, którego fundamenty zostały wykorzystane podczas budowy bramy wjazdowej do klasztoru.

Głównym celem badań archeologicznych w siedzibie Niemcewiczów w Skokach, (rejon brzeski) pochodzącej z XVIII wieku, było poszukiwanie reliktów dawnej zabudowy. Podczas badań odkryto pozostałości po zachodniej oficynie, zniszczonej w latach 60. XX wieku. Fundament budynku oraz inne elementy konstrukcji zachowały się w stanie dobrym. W trakcie prac archeologicznych odnaleziono interesujący zbiór zabytków datowanych na XVII-XX wiek. Zachodnia oficyna została zbadana tylko w $60 \%$. Prace archeologiczne zawieszono $\mathrm{z}$ powodu problemów finansowych. Odkryte już części zabudowy czekają na konserwację, bądź na całkowitą renowację.

Pomimo istniejących problemów i trudności z renowacją, odbudową zabytków i zachowaniem dziedzictwa kulturowego, w ostatnich latach badania archeologiczne w ramach prac konserwatorskich i restauracyjnych na obszarze południowo-zachodniej Białorusi przyniosły znaczące wyniki. 

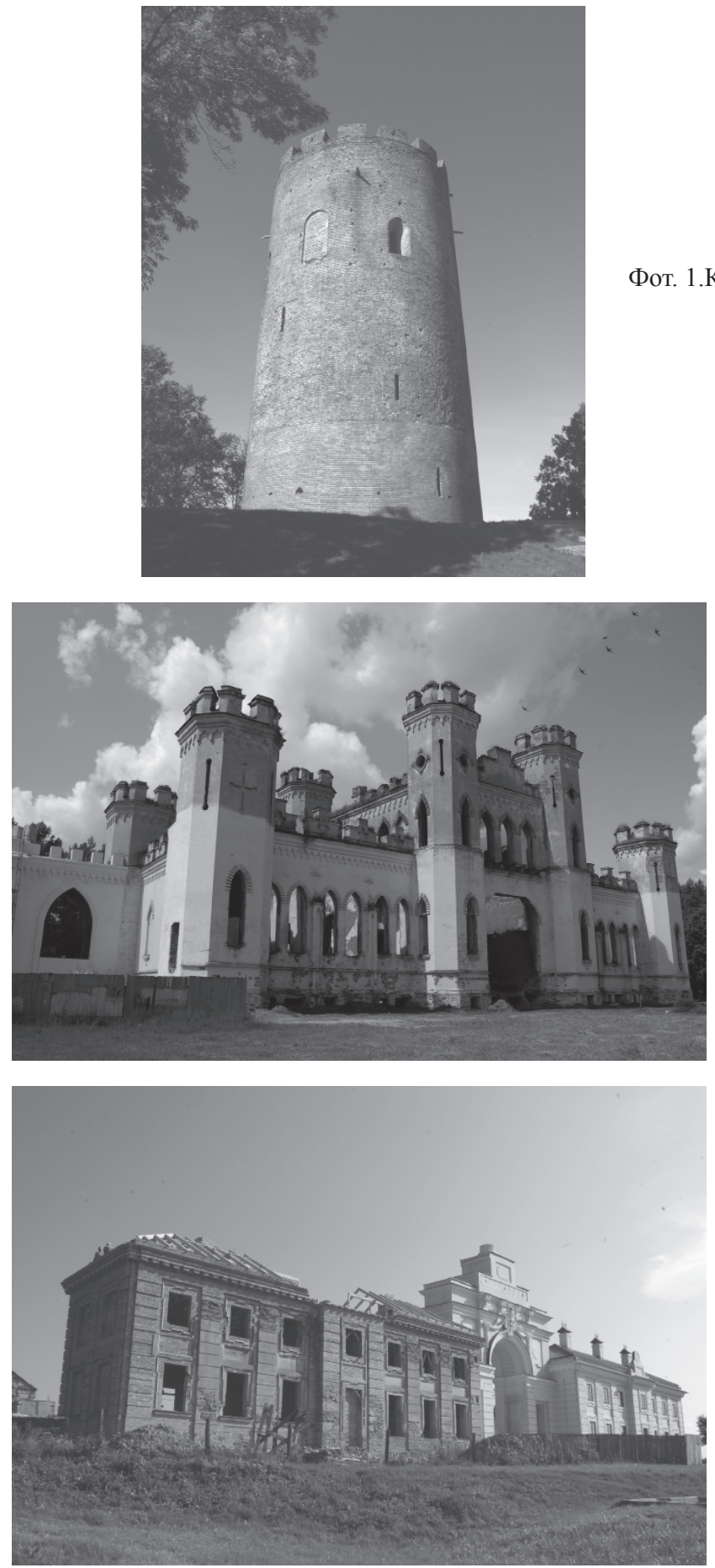

Фот. 1.Камянец. Абарончая вежа, 70-я гг. ХІІІ ст.

(Fot. А. Башкоў)

Фот. 2. Косаво. Палац Пуслоўскіх, 40-я гг. ХІХ ст. (Fot. А. Башкоў)

Фот. 3. Ружаны. Уяздная брама ў палац Сапегаў, 70-я гг. XVIII ст. (Fot. А. Башкоў) 
Фот. 4. Заказель. Радавая капліца Ажэшкаў, 40-я гг. XIX ст. (Fot. А. Башкоў)

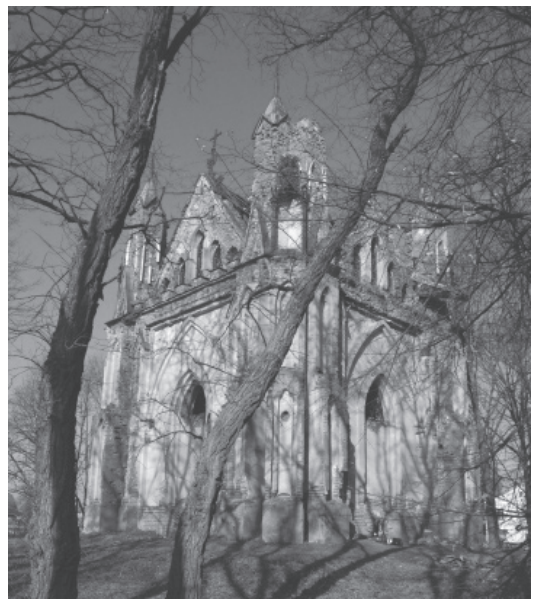

Фот. 5. Бяроза.

Уяздная брама ў кляштар картэзіянцаў,

II п. XVII ст.

(Fot. А. Башкоў)

Фот. 6. Скокі.

Палац Нямцэвічаў, 70-я гг. XVIII ст. (Fot. A. Башкоў)
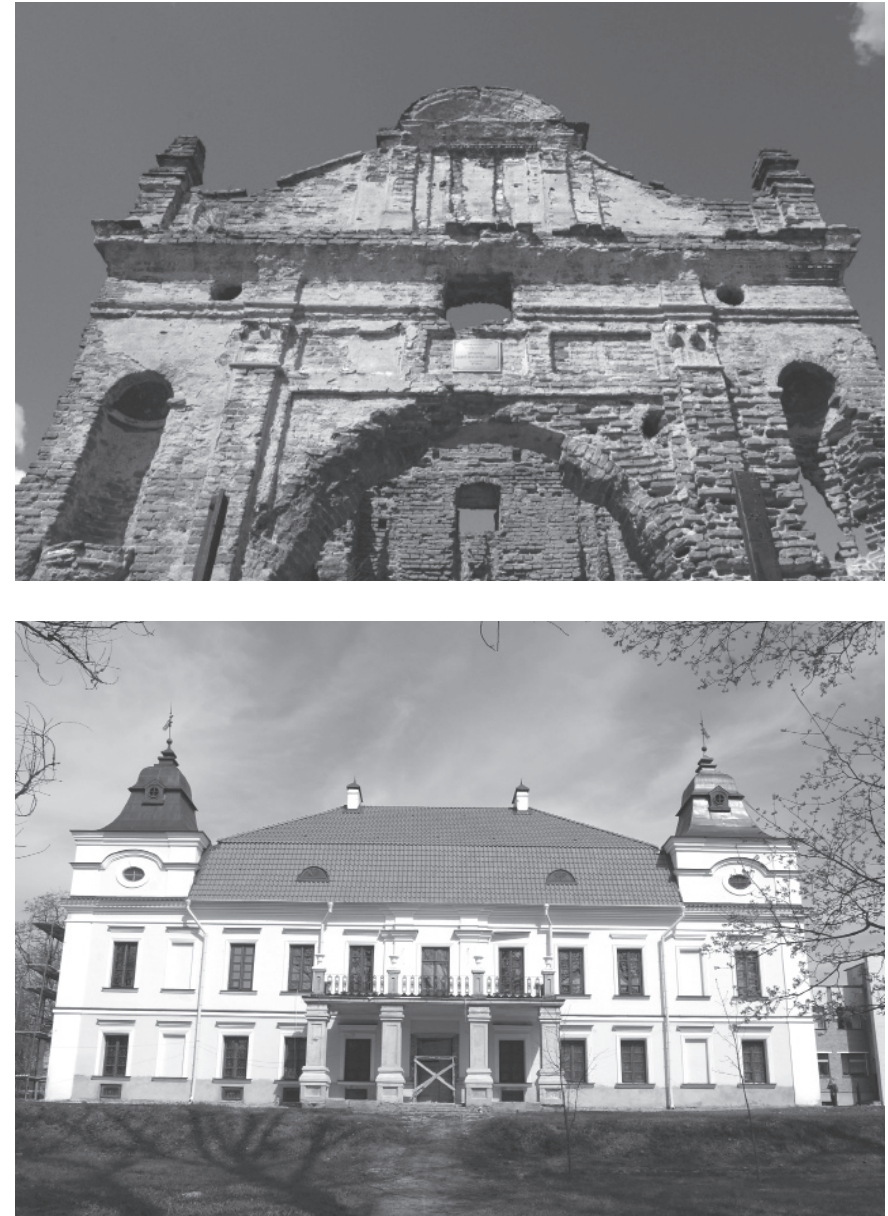